\title{
Investigating Female Customer's Impulse Buying in Facebook B2C Social Commerce: An Experimental Study
}

\author{
Jengchung Victor Chen \\ Institute of International Management, National Cheng Kung University, Taiwan \\ E-mail: victor@mail.ncku.edu.tw \\ Waranuch Chotimapruek \\ Institute of International Management, National Cheng Kung University, Taiwan \\ E-mail: buay aengka@hotmail.com \\ Quang-An Ha \\ School of International Business and Marketing, \\ University of Economics Ho Chi Minh City, Vietnam \\ E-mail: anhq@ueh.edu.vn \\ Andree E. Widjaja* \\ Department of Information System, Universitas Pelita Harapan, Indonesia \\ E-mail: andree.widjaja@uph.edu
}

\begin{abstract}
Along with the popularity of social network sites, social commerce such as Facebook has rapidly become a promising platform to conduct online advertisings and business activities. Drawing from Latent State-Trait theory (LST), we conducted an online experiment to empirically investigate the impact of information quality, picture of product presentation, the number of people's "Likes" and impulsiveness on female customer's urge to buy impulsively as well as the interaction effect of environmental cues and individual trait. The results showed that information quality, picture of product presentation, and impulsiveness positively affected the urge to buy impulsively. Contrary to our expectation, only information quality was found to interact with impulsiveness to jointly influence impulsive buying behavior, while the interaction of impulsiveness with product presentation and the number of likes was insignificant. The findings not only help to enrich our understanding of important factors influencing
\end{abstract}


impulse buying within Facebook B2C social commerce but also offer social commerce practitioners a better strategy in selling their products and services, specifically for female customers.

Keywords: Facebook social commerce, People's like, Information quality, Picture of product presentation, Impulsiveness, Latent State-Trait Theory (LST), Urge to buy impulsively

\section{INTRODUCTION}

Given the increased popularity of social networking sites, such as Facebook, there have been many opportunities to conduct a new business platform in e-commerce, known as social commerce (Abdelsalam et al., 2020; Chiang et al., 2019; Liang et al., 2011). For instance, when browsing around a Facebook store, a user can quickly decide to buy a product after they feel attracted to the stimuli or experience an urge to buy the products or services. With the continued growth of online shopping stores existing in social network sites (e.g., Facebook), it is of critical importance to gain more insights into the various factors that could trigger consumers' impulse buying behavior within this relatively new commerce platform.

Impulse buying occurs when an individual gets involved in the stimuli and experiences an urge to buy a product without a prior plan or proper reason for buying that product (Amos et al., 2014). To date, the research on impulse buying is very popular (Amos et al., 2014; Chan et al., 2017; Lu \& Wu, 2019; Lyer et al., 2020). The phenomenon of online impulse buying has been extensively studied in general online contexts(Chan et al., 2017; Sundström et al., 2019; I.-L. Wu et al., 2020; Y. Wu et al., 2020; Zheng et al., 2019) and in social commerce contexts(Abdelsalam et al., 2020; Chen et al., 2016; Chen et al., 2019; Leong et al., 2018; Liu et al., 2019; Setyani et al., 2019; Vazquez et al., 2020; Xiang et al., 2016; Xu et al., 2020).

Due to the increasing development of social commerce in recent years, an increasing number of studies have begun looking into customer's impulsive behavior within the social commerce context. For instance, drawing from parasocial interaction theory, Xiang et al. (2016) specifically investigated image-sharing social commerce platforms, which target women and "soft products". The findings demonstrated that parasocial interaction, which is determined by social features including similarity, expertise, the likeability of the platform, would enhance an individual's tendency to buy impulsively, while perceived enjoyment and impulsive tendency jointly impact the urge to buy impulsively. As Facebook has become a popular tool for marketing (RamsaranFowdar \& Fowdar, 2013), some prior studies have begun to focus their research within the Facebook context. For example, Chen et al.(2016)'s study on Facebook C2C social 
commerce platform found out that six dimensions of textual information quality (relevance, ease of understanding, accuracy, completeness, format, and currency), number of likes, and impulsiveness significantly contribute to the subsequent consumer's urge to buy impulsively. A more recent study conducted by Setyani et al. (2019) explored the impact of personalized advertisements on the urge to buy impulsively on Facebook. Their study found interesting results about the psychological mechanism underlying a consumer's reaction, which affecting impulse buying. The three aforementioned prior studies inferred that the impulse buying phenomenon does exist and plays a focal part in social commerce.

To the best of our knowledge, although impulsive buying in social commerce has been studied by several previous studies, the specific Facebook business-to-consumer (B2C) social commerce platform has rarely been empirically investigated. Meanwhile, research in the context of social commerce that exclusively focused on female customers has also rarely been given much attention in the extant online impulse buying-related literature. Thus, we aim to fill the aforementioned research gaps by answering the following two research questions: First, which salient factors would influence the female customer's impulse buying within the Facebook B2C social commerce context? Second, how can those factors interact and then influence the female customer's impulse buying? Based on the research questions, this research proposed two main objectives. First, we aimed to investigate the impact of environmental cues (information quality, picture of product presentation, people's "Likes") and impulsiveness on the female customer's urge to buy impulsively. Second, we examined the moderating role of impulsiveness on the relationship between environmental factors and subsequent individual responses. This study would benefit social commerce practitioners in that they can better understand significant factors, which could exert influence on the female customer's urge to buy impulsively on social network sites such as Facebook.

\section{THEORETICAL BACKGROUND}

\section{Online Impulse Buying}

According to Beatty and Ferrell(1998), impulse buying is a sudden and immediate purchase without prior intention either to buy a specific product or to fulfill a specific buying task. Such buying behavior occurs spontaneously and without much reflection after consumers experience an urge to buy. In the context of online shopping, prior evidence has reported that consumer's impulsive buying could be influenced by several factors such as attractive merchandise, enjoyment, website's communication style (Verhagen \& Van Dolen, 2011), website quality (Wells et al., 2011), online platform's design and navigation (Floh \& Madlberger, 2013), visual appeal (Liu et al., 2013; Zheng 
et al., 2019), online product presentation (Vonkeman et al., 2017), e-store design (Lo et al., 2016; I.-L. Wu et al., 2020), social comparison (Liu et al., 2019), product recommendation (Chen et al., 2019), online reviews (Xu et al., 2020), and many others. Through extensive studies on impulsive buying in the context of ordinary online shopping websites, to date, there has been little discussion about the phenomenon of impulse buying behavior within Facebook B2C social commerce.

\section{Social Commerce}

Along with the increasing popularity of social network sites such as Facebook, Twitter, and Instagram, a new business model of e-commerce called social commerce has emerged (Abdelsalam et al., 2020; Liang \& Turban, 2011). This new platform is a subset of e-commerce that utilizes social media to conduct commercial activities and transactions (Liang \& Turban, 2011). Several other studies broadly referred to social commerce as the platform with two crucial elements, which are social media and commercial activities. Accordingly, there are two main types of social commerce; one is established social network sites that integrate commercial features to aid transaction activities, the other is traditional e-commerce websites that offer additional social functions to boost social interaction and sharing among online consumers (Liang \& Turban, 2011; Zhang \& Benyoucef, 2016). Due to the integration of social site features, social commerce allows users to interact with others, contribute and distribute their content while experiencing online shopping (Liang \& Turban, 2011). It is also considered the most distinct difference between social commerce and e-commerce, which mainly emphasizes the efficiency of the transaction (Wang \& Zhang, 2012). Social commerce has increasingly become an attractive choice of small business retailers due to its easy, convenient, and inexpensive method of developing a business model (Abdelsalam et al., 2020; Yadav et al., 2013).

Social commerce has become an important topic in the literature of information systems and marketing(Abdelsalam et al., 2020). According to Zhang and Benyoucef (2016), there are two streams of research contexts: social networking sites in general and brand pages. The latter stream attracts more recent papers due to its practical importance in providing companies with more valuable insights into consumer buying behavior (Zhang \& Benyoucef, 2016). Prior studies have investigated social commerce from different perspectives such as consumer adoption (Hajli, 2013; Hajli, 2015; Teh \& Ahmed, 2012), continuance intention (Liang et al., 2011), trust in social commerce (Hajli, 2015; Kim \& Park, 2013), and impulse buying (Chen et al., 2016; Setyani et al., 2019). In this study, we limited our examination to the first type of social commerce, which is a commercial transaction conducted in established social network sites. To be 
more specific, brand pages created by companies to promote brands and interact with consumers, or Facebook B2C social commerce, would be our focus.

\section{Latent State-Trait Theory}

Latent State-Trait theory (LST) proposed by Steyer et al.(1999) has been widely applied in psychological research. The theory states that human behavior is dependent on environmental cues or situations, individual traits, and the interplay between these two determinants (Steyer et al., 1999). According to Hertzog and Nesselroade (1987), a trait is referred to individual characteristics that remain relatively stable across situations and can be used to differentiate two people. Prior studies drawing from LST theory have investigated the consumer's urge to buy impulsively in the context of ecommerce and social commerce. The finding reported that consumer's impulsive behavior was positively correlated with website quality (Wells et al., 2011), information quality, and the number of likes (Chen et al., 2016). Based on LST theory, this study operationalized environmental characteristics as people "like", information quality, and picture of product presentation; individual traits as impulsiveness. These environmental cues are considered the main factors when consumers browse a Facebook Store and consider buying products on Facebook. Figure 1 depicts our research framework.

Figure 1 Research Model

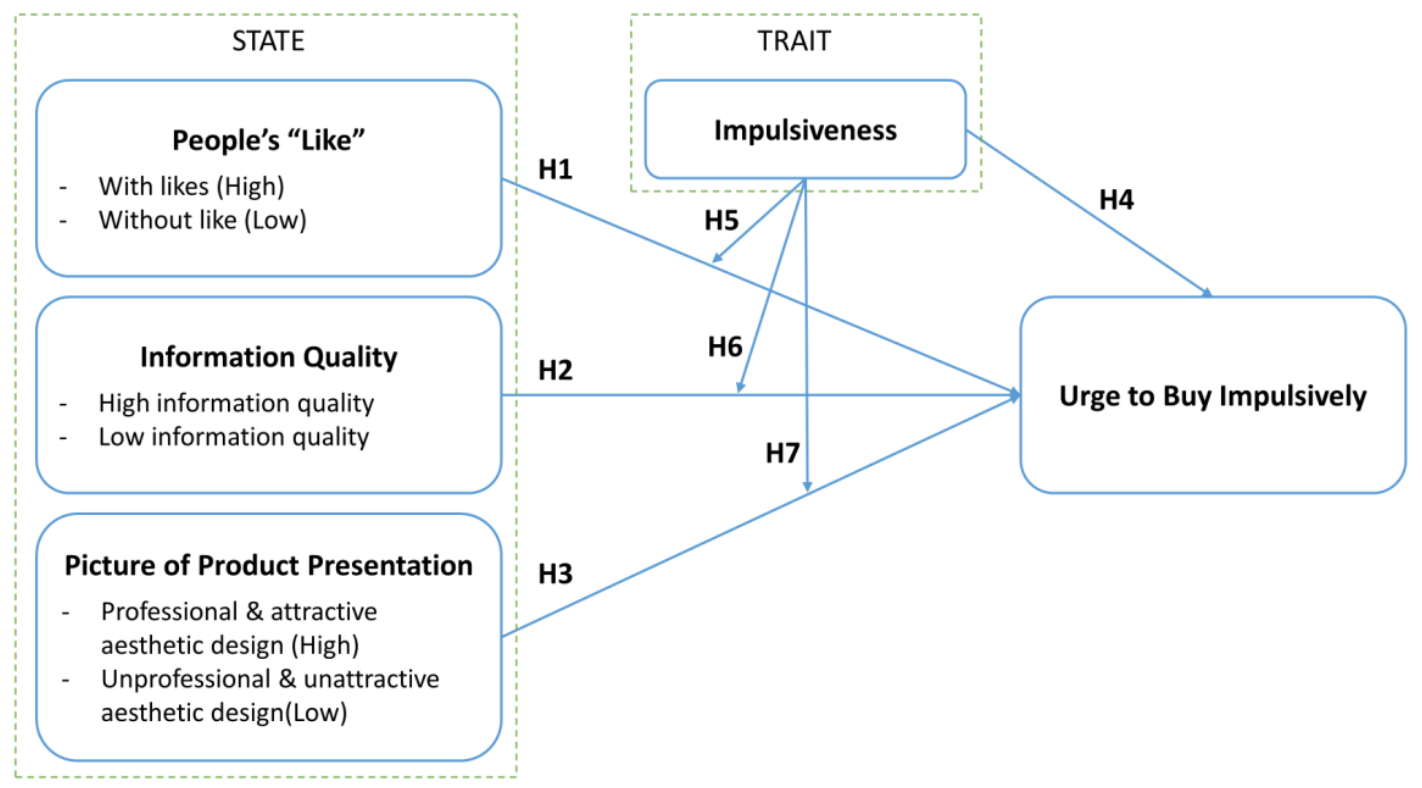

\section{Hypothesis Development}

Urge to buy impulsively 
Beatty and Ferrell (1998) defined the urge to buy impulsively as "the state of urge desire that is experienced upon encountering an object in the environment". The urge to buy impulsively is claimed to be a reliable antecedent of actual impulsive buying behavior in both online (Liu et al., 2013; Parboteeah et al., 2009) and offline settings (Badgaiyan \& Verma, 2015; Beatty \& Ferrell, 1998; Harmancioglu et al., 2009). For this reason, we also considered this measure to be an appropriate and effective surrogate for impulse buying behavior.

\section{Facebook "Like" button}

As stated on Facebook.com, the "like" button might represent a way of giving a positive reaction and thus becomes an easy way to make others know your reaction without giving any comments. When Facebook users press the "like" button on a post, such content will automatically appear in the newsfeed of the users' friends, which consequently can create e-Word of Mouth (eWOM) (Pual \& Richard, 2010). Meanwhile, prior evidence of eWOM claimed that eWOM would effectively influence consumers' decision-making (Hennig-Thurau et al., 2004; Hennig-Thurau \& Walsh, 2003). Liang and Turban (2011) also added that word of mouth and any activities in social network sites would possibly affect user's attitudes and behavior. Meanwhile, a prior study on WeChat social commerce indicated that product recommendations could also affect impulse buying (Chen et al., 2019). Hence, it is expected that the Facebook "like" button could exert an impact on individual behavior in social commerce platforms through the effect of eWOM as well as product recommendations.

In this study, the "like" construct is divided into two extreme manipulations: With People "Like" (high) and Without People "Like" (low). "With People "Like" (high)" is operationalized when several Facebook users give good comments on the product posted on the Facebook page by clicking the "like" button, while "Without People's "Like"(low)" means having no "like". Based on the arguments, it is hypothesized that:

H1: Facebook users are likely to have a stronger urge to buy impulsively under the condition of with People's "Like" rather than without People's "Like"

\section{Information quality}

In the e-commerce context, information quality is defined as a consumer's general perception of the accuracy and completeness of website information. According to Montoya-Weiss et al. (2003), content covers all available information on the website, such as product information, price, contact (Floh \& Madlberger, 2013). Information quality itself has been found to increase customers' attitudes toward the website (Chen et al., 2002), customer satisfaction (Kuo et al., 2005), customer loyalty (Mithas et al., 
2007), intention to purchase (Bharati \& Chaudhury, 2006; Cao et al., 2005), and use of online channels (Montoya-Weiss et al., 2003). In the settings of Facebook C2C social commerce, Chen et al. (2016) indicated that those being exposed to an advertisement with a higher level of information quality in terms of relevance, ease of understanding, accuracy, completeness, format, and currency would demonstrate a higher urge to buy impulsively. Wells et al. (2011) also proved the important role of the varying degree of website quality on consumers' impulsive buying in an e-commerce platform.

In this study, we operationalized the information quality of advertisements posted on a Facebook page as an environmental characteristic influencing consumers' urge to buy impulsively. We expect that under the high condition of information quality, consumers would exhibit a greater urge to buy impulsively. Thus, it is hypothesized:

H2: Facebook users are likely to have a stronger urge to buy impulsively under the condition of high information quality rather than low information quality.

\section{Picture of product presentation quality}

Pictures are generally used to portray the visual appeal of the product (Baggett, 1989). The inadequate presentation richness of a product in an online environment is a significant obstacle to e-commerce retailers(Jiang \& Benbasat, 2007). Many scholars proposed that pictures could be used to enhance the effectiveness of advertising towards customer's attitudes and behavior (Leong, 1996; Unnava \& Burnkrant, 1991). For instance, Miyoung and Jiyoung(2008) found that the realism of picture presentations would influence consumers' attitudes towards e-commerce websites. Another study by Floh and Madlberger (2013)indicated that visual appeal positively influences online impulse buying behavior, which is mediated by shopping enjoyment. Perception of product presentation technologies in terms of interactivity and vividness is found to significantly enhance individual presence (i.e., a sense of the product being present with the consumer in his or her environment), which consequently leads to the urge to buy impulsively (Vonkeman et al., 2017). In a similar vein, another study also demonstrated the salient effect of visual appeal (Zheng et al., 2019) on impulse buying.

In this study, we expect a positive relationship between pictures of product presentations posted on a Facebook page and the consumers' urge to buy impulsively. Adapted from Well et al. (2011), pictures of product presentation were measured by two dimensions: professional and attractive aesthetic design (high level) and unprofessional and unattractive aesthetic design (low level). The more professional and attractive the picture of product presentation is, the greater the urge to buy impulsively, consumers would feel. Thus, we hypothesized that: 
H3: Facebook users are likely to have a stronger urge to buy impulsively under the condition of pictures with professional and attractive aesthetic design rather than pictures with unprofessional and unattractive aesthetic design.

\section{Impulsiveness}

Impulsiveness was proposed by Beatty and Ferrell(1998) as "the tendencies to (1) experience spontaneous and sudden urges to make on-the-spot purchases and (2) to act on those urges with little deliberation or evaluation of consequence". People with impulsive buying dispositions are more likely to purchase suddenly and spontaneously. Impulse buying tendency has been widely studied in both traditional and online settings. In the offline shopping context, Beatty and Ferrel (1998) further indicated that those who possess a higher level of impulsiveness would have a greater tendency to endure the urge to buy impulsively and respond to that urge. Past studies on e-commerce also showed that impulsiveness would significantly influence shopping intention (Zhang et al., 2006), the urge to buy impulsively (Chen et al., 2016; Wells et al., 2011), and actual impulse buying behavior (Floh \& Madlberger, 2013). In this study, we expect that the positive relationship between impulsive disposition and the urge to buy impulsively would exist in Facebook B2C social commerce as well. We hypothesized that:

H4: Facebook users with high impulsiveness will experience a stronger urge to buy impulsively compared to Facebook users with low impulsiveness.

\section{The interaction effect}

Hertzog and Nesselroade (1987) proposed that the interplay between individual characteristics and environmental cues should be paid more attention to gain a more insightful understanding in explaining online impulse buying. Though the direct influence of impulsiveness on consumer's buying behavior has been widely proved, its interaction effect with environmental cues has been reported with mixed results. Youn and Faber (2000) showed that consumers with a higher level of impulsiveness would be more reactive to environmental cues, which triggers them to be more likely to experience the urge of impulse buying.

A study by Chen et al. (2016) demonstrated the partial interaction effect of textual information quality and impulsiveness on a consumer's urge to buy impulsively. Specifically, among six proposed dimensions of information quality (relevance, accuracy, ease of understanding, completeness, format, and currency), impulsiveness only jointly interacted with two aspects, namely completeness and format. In a high condition of format (i.e., the posted information is well-formatted), only low impulsive individuals were significantly influenced by the increased level of completeness, which 
considerably enhanced their urge to buy impulsively. Conversely, when it comes to low format, highly impulsive consumers would experience greater positive change in the urge to buy impulsively when the information is complete. In this study, we expect that impulsive tendency would jointly interact with environmental cues in B2C social commerce, causing a varying degree of consumer's urge to buy impulsively. We, therefore, propose the following hypotheses:

H5: Impulsiveness Significantly Moderates the Relationship between People's Like and Urge to Buy Impulsively

H6: Impulsiveness Significantly Moderates the Relationship between Information Quality and Urge to Buy Impulsively

H7: Impulsiveness Significantly Moderates the Relationship between Picture of Product Presentation and Urge to Buy Impulsively

\section{Control variables}

Factors such as age, educational status, employment status, monthly income, and monthly spending budget were used as control variables that might influence individuals to buy impulsively. Age has been found to play an important role in influencing consumers' impulse buying (Kacen \& Lee, 2002). Meanwhile, March and Woodside (2005) indicated that educational status and employment status are negatively correlated with impulse buying. Thus, both factors were included to analyze and reaffirm the relationship as to control variables toward the urge to buy impulsively. Kumar and Mishra (2012) proposed that individuals with higher income would possess a greater tendency to experience impulsive buying. Such argument is contrary to Jeffrey and Hodge's (2007) study, which reported the negative relationship between these two variables.

\section{RESEARCH METHODOLOGY}

\section{Experimental Design}

This study employed a 2 (People's "Like": with or without) x 2 (Information quality: high or low) $\mathrm{x} 2$ (Picture of product presentation: with professional and attractive aesthetic design or with unprofessional and unattractive aesthetic design) full factorial between-subject experimental design. Accordingly, eight different fictitious Facebook stores were created. 
Table 1 Experimental Design

\begin{tabular}{|c|c|c|c|c|}
\hline \multirow{2}{*}{$\begin{array}{c}\text { Information } \\
\text { Quality }\end{array}$} & \multicolumn{2}{|c|}{$\begin{array}{c}\text { With Professional \& Attractive } \\
\text { Aesthetic Design }\end{array}$} & $\begin{array}{c}\text { With Unprofessional \& Unattractive } \\
\text { Aesthetic Design }\end{array}$ \\
\cline { 2 - 5 } & $\begin{array}{c}\text { With People's } \\
\text { "Like" } \\
\text { (High) }\end{array}$ & $\begin{array}{c}\text { Without } \\
\text { People's "Like" } \\
\text { (Low) }\end{array}$ & $\begin{array}{c}\text { With People's } \\
\text { "Like" } \\
\text { (High) }\end{array}$ & $\begin{array}{c}\text { Without People's } \\
\text { "Like" } \\
\text { (Low) }\end{array}$ \\
\hline $\begin{array}{c}\text { High information } \\
\text { quality }\end{array}$ & A-01 (30) & A-02 (30) & A-03 (30) & A-04 (30) \\
\hline $\begin{array}{c}\text { Low information } \\
\text { quality }\end{array}$ & B-01 (30) & B-02 (30) & B-03 (30) & B-04 (30) \\
\hline
\end{tabular}

\section{Stimuli Development and Experimental Procedure}

The stimuli for this experimental research were presented on Facebook Pages. We created a fictitious Facebook store on a Facebook Page called Vanilla Shop, which sold fashion products (working clothes for females). Previous impulse buying studies also focused on impulse fashion buying behavior online (Sundström et al., 2019). Unlike the previous studies, this study specifically focused on females as the research subject because it was realized that impulse buying behavior occurs more frequently with females than males. Prior studies' demographic characteristics showed that the majority of the respondents admitting having been involved in prior impulse buying were female (e.g., Floh and Madlberger(2013) and Verhagen and Van Dolen (2011)). Moreover, according to a survey conducted by the Thai Electronic Transactions Development Agency (ETDA, 2020), a female aged between 20 and 34 was reported to conduct more online transactions in social media. This survey also indicated that fashion products (clothes, shoes, bags) accounted for the largest category purchased by Thai internet users. Another reason for choosing female fashion products is that such products are considered hedonic products, which are more likely to trigger a consumer's affective responses, enhance self-image and result in impulsive decision making (Verhagen \& Van Dolen, 2011).

We distributed the experimental website link through several Facebook stores (Panicloset, Lacecoat - the biggest Facebook stores selling women's clothes in Thailand) and shopping forums (Pantip.com - the biggest forum website in Thailand). To make sure that all participants are female, we clearly stated that only females are eligible for the study before participants started the experiment. Once clicking through the main link, participants were randomly assigned to one of eight treatment pages. After the respondents accessed the experiment page, we briefly introduced the purpose of this experimental study and step-by-step instructions. The respondents then followed three 
steps. First, we gave the respondents a scenario with a precise shopping task, adopted from Wells et al. (2011). Rook and Fisher (1995) posited that creating the scenario would help respondents to participate actively in the shopping task, and impulsive buyers would be likely to behave impulsively. Next, the respondents were asked to visit the fictitious Facebook Page (Facebook store) called Vanilla Shop and browse the products. Finally, they were required to fill in an online questionnaire, including questions for manipulation check, measuring impulsive buying behavior, and demographic information.

\section{Sample, Data Collection, and Measurements}

The target respondents were female Facebook users in Thailand. We employed a convenience sampling method to recruit respondents for the study. For the incentives, five movie tickets and 5 Starbucks gift cards were randomly awarded to 10 participants. We collected a total of 290 responses, among which 240 responses were valid and could be used for further data analysis (50 responses were invalid mainly due to the incomplete data, thereby the responses were excluded). Each treatment page consisted of 30 samples (as shown in Table 1 - experimental design).

The measurements used in this study were adapted from prior work. Impulsiveness was measured using four items from the Buying Impulsiveness Scale adopted from Rook and Fisher (1995) and Wells et al. (2011). The urge to buy impulsively scale (UBI) was adopted from Parboteeah et al.(2009). Respondents were also asked to fill in their personal information and demographic profiles. For the sake of respondents' privacy concerns, all collected data were kept confidential.

\section{Manipulation Check}

The manipulation check was conducted to confirm whether our manipulation (treatment) had worked or not. A manipulation check for People's "Like" was employed to see if the participants could perceive any difference between 'With People's "Like"(high)' and 'Without People's 'Like"(low)' on pictures of the products posted. The respondents were asked to rate the two following questions on a 7-point Likert scale.

1. Do you consider the number of people "Like" to decide on shopping on Facebook? (Strongly disagree... Strongly agree).

2. In your opinion, please rate the number of like as shown in the picture (Very low... Very high).

A manipulation check for "Information quality" was performed to see if the participants could perceive any difference between "high information quality" and "low 
information quality" on the information of the products posted. The respondents were asked to rate the four following statements on a 7-point Likert scale.

1. Overall, I think this Facebook page provides useful information. 'Not relevant''relevant' (Floh \& Madlberger, 2013).

2. In my opinion, the Facebook page provides detailed information that is relevant to consumer needs. 'Very low' - 'very high' (Wixom \& Todd, 2005).

3. In general, this Facebook page provides me with high-quality information.

4. Overall, I would give the information provided by the Facebook page a high rating in terms of quality.

A manipulation check for 'Picture of product presentation' was performed to see if the participants could perceive any difference between 'with professional and attractive aesthetic design (high)' and 'with unprofessional and unattractive aesthetic design (low)' on the picture of products posted. The respondents were asked to rate the two following statements adopted from Vance et al. (2008) on a 7-point Likert scale from 'Strongly disagree' to 'strongly agree'.

1. I like the look and feel of this picture.

2. The picture of the product that is posted on the Facebook page is attractive.

\section{RESULTS AND ANALYSIS}

\section{Demographics}

Among the 240 respondents, all were females, and nearly $80 \%$ of the respondents were between 21-30 years old. More than $82 \%$ of the overall respondents had online shopping experiences on Facebook. Regarding education, 51\% had a Bachelor's degree while $46 \%$ had a Master's degree. The majority of the participants were current fulltime employees (79.6\%), had an average income of THB15,000-35,000 (50\%), spent THB 10,000 - 20,000 monthly (38.3\%). About their experience in social media, more than $71 \%$ of the respondents had used Facebook for more than four years, $45 \%$ spent more than 2 hours on Facebook daily, and 39\% had more than 400 friends on Facebook. Most of the participants had experienced online shopping on Facebook (85\%), purchased 0-3 times per half-year on Facebook (68\%). Table 2 reports the demographics data. 
Table 2 Demographics

\begin{tabular}{|c|c|c|}
\hline \multirow{2}{*}{ Items } & \multicolumn{2}{|c|}{ Respondents $(n=240)$} \\
\hline & Frequency & $(\%)$ \\
\hline \multicolumn{3}{|c|}{ Age } \\
\hline 21 to 30 years old & 191 & 79.6 \\
\hline 31 to 40 years old & 46 & 19.2 \\
\hline 41 to 50 years old & 2 & 0.8 \\
\hline More than 50 years old & 1 & 0.4 \\
\hline \multicolumn{3}{|c|}{ Educational Attainment } \\
\hline High School & 2 & 0.8 \\
\hline Bachelor degree & 123 & 51.3 \\
\hline Master's degree & 111 & 46.3 \\
\hline Doctoral degree & 4 & 1.7 \\
\hline \multicolumn{3}{|c|}{ Employment Status } \\
\hline Employed full time & 191 & 79.6 \\
\hline Employee part-time & 6 & 2.5 \\
\hline Self- employed & 43 & 17.9 \\
\hline \multicolumn{3}{|c|}{ Occupation } \\
\hline Business employee & 168 & 70 \\
\hline Business owner & 43 & 17.9 \\
\hline Government official & 12 & 5 \\
\hline NGO & 1 & 0.4 \\
\hline State enterprise officer & 16 & 6.7 \\
\hline \multicolumn{3}{|c|}{ Monthly Income } \\
\hline Less than THB 15,000 & 19 & 7.9 \\
\hline THB $15,000-25,000$ & 60 & 25 \\
\hline THB 25,001-35,000 & 60 & 25 \\
\hline THB $35,001-45,000$ & 48 & 20 \\
\hline More than THB 45,000 & 53 & 22.1 \\
\hline \multicolumn{3}{|c|}{ Monthly Spending Budget } \\
\hline Less than THB 5,000 & 15 & 6.3 \\
\hline THB 5,000 - 10,000 & 63 & 26.3 \\
\hline THB $10,000-20,000$ & 92 & 38.3 \\
\hline THB $20,001-30,000$ & 43 & 17.9 \\
\hline More than THB 30,000 & 27 & 11.3 \\
\hline \multicolumn{3}{|c|}{ Years using Facebook } \\
\hline 1 to 2 years & 8 & 3.3 \\
\hline 2 to 3 years & 11 & 4.6 \\
\hline 3 to 4 years & 1 & 0.4 \\
\hline 4 to 5 years & 48 & 20 \\
\hline More than 5 years & 172 & 71.7 \\
\hline
\end{tabular}


Table 2 Demographics (con.)

\begin{tabular}{|c|c|c|}
\hline \multicolumn{2}{|c|}{ Time to use Facebook per day } \\
\hline Less than 10 minutes & 10 & 4.2 \\
\hline 10 to 30 minutes & 29 & 12.1 \\
\hline 30 minutes to 1 hour & 41 & 17.1 \\
\hline 1 to 2 hours & 51 & 21.3 \\
\hline More than 2 hours & 109 & 45.4 \\
\hline Number of friends on Facebook & 5.4 \\
\hline Less than 100 & 13 & 15.4 \\
\hline $101-200$ & 37 & 22.5 \\
\hline $201-300$ & 54 & 17.5 \\
\hline $301-400$ & 42 & 39.2 \\
\hline More than 400 & 94 & 82.5 \\
\hline The shopping experience on Facebook & 17.5 \\
\hline Yes & 198 & 35.4 \\
\hline No & 42 & 32.9 \\
\hline The frequency of buying products on Facebook (Per half year) \\
\hline More than 1 time to 3 times & 85 & 14.6 \\
\hline More than 3 times to 5 times & 79 & 6.3 \\
\hline More than 5 times to 7 times & 35 & 10.8 \\
\hline More than 7 times & 15 & \\
\hline
\end{tabular}

\section{Confirmatory Factor Analysis and Reliability Analysis}

AMOS 18.0 was employed to analyze the reliability of our data. The rule of thumb as proposed by Hair et al. (2010) was used to assess the factor loading and the goodnessof-fit of our model:factor loading > 0.6 Chi-Square / d. f. < 3 good , CFI > 0.95 great; $>0.90$ traditional; $>0.80$ sometimes permissible, RMSEA < 0.05; 0.50-0.10 moderate; $>0.10$ bad, GFI > 0.95; AGFI >0.80. The results showed the acceptable model fit with the satisfactory result of Chi-Square/d. f. range, AGFI, CFI, and RMSEA. Only GFI was not greater than 0.95; however, its value is considered acceptable due to its close value to the criteria. Meanwhile, Hair et al. (2010) also suggested the threshold for convergent validity were $\mathrm{CR}>(\mathrm{AVE})$; $\mathrm{AVE}>0.50$. The statistical results generally indicated that all of the constructs used in this study showed good reliability, which was greater than the minimum threshold of 0.7 (Nunnally \& Bernstein, 1994). Table 3 and Table 4 show the result of CFAand construct correlations, reliabilities, average variance extracted. 
Table 3 CFA Results

\begin{tabular}{|c|c|c|c|}
\hline Construct & Variable & Research Items & $\begin{array}{l}\text { Factor } \\
\text { Loading }\end{array}$ \\
\hline \multirow{4}{*}{$\begin{array}{l}\text { Information } \\
\text { Quality }\end{array}$} & Inf1 & $\begin{array}{l}\text { Overall, I think that Vanilla Shop (Facebook store) } \\
\text { provides useful information about the product }\end{array}$ & 0.904 \\
\hline & Inf2 & $\begin{array}{l}\text { In my opinion, Vanilla Shop (Facebook store) } \\
\text { provides detailed information of the product that is } \\
\text { relevant to consumer needs }\end{array}$ & 0.902 \\
\hline & Inf3 & $\begin{array}{l}\text { In general, Vanilla Shop (Facebook store) provides } \\
\text { me with high-quality information of the product }\end{array}$ & 0.938 \\
\hline & Inf4 & $\begin{array}{l}\text { Overall, I would give the information about } \\
\text { products provided by the Facebook store a high } \\
\text { rating in terms of quality }\end{array}$ & 0.957 \\
\hline \multirow{2}{*}{$\begin{array}{l}\text { Picture of } \\
\text { Product } \\
\text { Presentation }\end{array}$} & Pic1 & $\begin{array}{l}\text { I like the look and feel of the picture of the product } \\
\text { in Vanilla Shop (Facebook store) }\end{array}$ & 0.941 \\
\hline & Pic2 & $\begin{array}{l}\text { The picture of the product posted on Vanilla Shop } \\
\text { (Facebook store) is attractive }\end{array}$ & 0.881 \\
\hline \multirow{4}{*}{ Impulsiveness } & Ips1 & "Just do it" describes the way I buy products & 0.801 \\
\hline & Ips2 & I often buy products without thinking & 0.812 \\
\hline & Ips3 & "I see it, I buy it" describes me & 0.884 \\
\hline & Ips4 & "Buy now, think about it later" describes me & 0.85 \\
\hline \multirow{3}{*}{$\begin{array}{l}\text { Urge to Buy } \\
\text { Impulsively }\end{array}$} & Urge1 & $\begin{array}{l}\text { As I browsed the Facebook page, I had the urge to } \\
\text { purchase items other than or in addition to my } \\
\text { specific shopping goal }\end{array}$ & 0.717 \\
\hline & Urge 2 & $\begin{array}{l}\text { Browsing this Facebook page, I had a desire to buy } \\
\text { items that did not pertain to my specific shopping } \\
\text { goal }\end{array}$ & 0.819 \\
\hline & Urge3 & $\begin{array}{l}\text { While browsing this Facebook Page, I was inclined } \\
\text { to purchase items outside my specific shopping goal }\end{array}$ & 0.875 \\
\hline
\end{tabular}

Table 4 Reliability Analysis and Correlations

\begin{tabular}{|c|c|c|c|c|c|c|}
\hline & CR & AVE & Urge & Ips & Inf & Pic \\
\hline Urge & 0.847 & 0.650 & $\mathbf{0 . 8 0 6}$ & & & \\
\hline Ips & 0.904 & 0.701 & 0.486 & $\mathbf{0 . 8 3 7}$ & & \\
\hline Inf & 0.960 & 0.857 & 0.326 & 0.163 & $\mathbf{0 . 9 2 6}$ & \\
\hline Pic & 0.908 & 0.831 & 0.384 & 0.205 & 0.604 & $\mathbf{0 . 9 1 1}$ \\
\hline
\end{tabular}

Note. $\mathrm{CR}=$ Composite Reliability, AVE= Average Variance Extracted, Square Root of AVE on

Diagonals

Urge= Urge to Buy Impulsively, Ips= Impulsiveness, Inf=Information Quality,

$\mathrm{Pic}=$ Picture of Product Presentation 


\section{Manipulation Check}

For the People's "Like" treatment, we considered the Facebook Page (The Facebook page of Vanilla Shop) with people clicking like on the products as high treatment, whereas the Facebook Page without people clicking like on products was considered as low treatment. The results indicated that the respondents did not perceive a clear difference between the low and high treatment groups (F-value $=0.005$, $\mathrm{p}=0.942$ ). Information quality was manipulated by showing a different level of product information detail stated on the Facebook page. The mean score of high information quality was 5.119 , whereas the mean score of low information quality was 3.171 ; the difference was significant $(\mathrm{F}$-value $=145.903, \mathrm{p}<0.001)$. As for the picture of product presentation, we considered the picture with professional and attractive design as high treatment, while the picture with unprofessional and unattractive design as low treatment. The mean score of the high treatment was 4.450 , whereas the mean of the low treatment was 3.900; the difference was significant $(\mathrm{F}$-value $=9.806, \mathrm{p}=0.002)$. In addition, since the Impulsiveness construct is a continuous variable, we employed the mean-splitting method (Hair et al., 2014) to categorize the high impulsiveness and low impulsiveness.

\section{Hypothesis Testing}

We ran between subject's ANOVA to test the proposed hypotheses. Based on the results (see Table 5), the urge to buy impulsively was positively affected by information quality $(\mathrm{F}=15.643, \mathrm{p}<0.001)$ and the picture of product presentation $(\mathrm{F}=4.357, \mathrm{p}=$ 0.038). Hence, hypotheses 2 and 3 are supported. Nevertheless, the number of People's "Likes" did not exert a direct effect on the dependent variable due to an insignificant Fvalue $(\mathrm{F}=1.031, \mathrm{p}=0.311)$. Hypothesis 1 , thus, was not supported. Impulsiveness positively influences the urge to buy impulsively $(\mathrm{F}=31.858, \mathrm{p}<0.001)$, hypothesis 4 was supported. 
Table 5 ANOVA Results

\begin{tabular}{|c|c|c|c|c|c|}
\hline Source & $\begin{array}{c}\text { Sum of } \\
\text { Squares }\end{array}$ & df & Mean Square & $\mathbf{F}$ & Sig. (P) \\
\hline \multicolumn{6}{|l|}{ Main Effects } \\
\hline Number of People's “Like” (LIKE) & 1.42 & 1 & 1.42 & 1.031 & 0.311 \\
\hline Information Quality (IQ) & 21.553 & 1 & 21.553 & 15.643 & 0.000 \\
\hline Picture of Product Presentation (PPP) & 6.004 & 1 & 6.004 & 4.357 & 0.038 \\
\hline Impulsiveness (IMP) & 43.895 & 1 & 43.895 & 31.858 & 0.000 \\
\hline \multicolumn{6}{|l|}{ Interaction Effects (Main study) } \\
\hline LIKE* IMP & 0.492 & 1 & 0.492 & 0.357 & 0.551 \\
\hline IQ* IMP & 6.894 & 1 & 6.894 & 5.003 & 0.026 \\
\hline PPP* IMP & 0.191 & 1 & 0.191 & 0.139 & 0.710 \\
\hline \multicolumn{6}{|l|}{ Interaction Effects (Further tested) } \\
\hline PPP * LIKE & 0.091 & 1 & 0.091 & 0.066 & 0.797 \\
\hline IQ * LIKE & 1.365 & 1 & 1.365 & 0.991 & 0.321 \\
\hline IQ * PPP & 6.013 & 1 & 6.013 & 4.364 & 0.038 \\
\hline IQ * PPP * LIKE & 0.817 & 1 & 0.817 & 0.593 & 0.442 \\
\hline $\mathrm{IQ} * \mathrm{PPP} * \mathrm{IMP}$ & 0.249 & 1 & 0.249 & 0.181 & 0.671 \\
\hline IQ * LIKE * IMP & 2.091 & 1 & 2.091 & 1.517 & 0.219 \\
\hline $\mathrm{PPP} * \mathrm{LIKE} * \mathrm{IMP}$ & 3.433 & 1 & 3.433 & 2.491 & 0.116 \\
\hline $\mathrm{IQ}^{*} \mathrm{PPP} * \mathrm{LIKE} * \mathrm{IMP}$ & 0.556 & 1 & 0.556 & 0.403 & 0.526 \\
\hline \multicolumn{6}{|c|}{ R-squared $=0.289($ Adjusted R -Squared $=.242)$} \\
\hline Comparison of means of main effects & \multicolumn{2}{|c|}{ Low } & High & \multicolumn{2}{|c|}{ Difference } \\
\hline Number of People's "Like" & \multicolumn{2}{|c|}{$3.847(1.406)$} & $4.011(1.288)$ & \multicolumn{2}{|c|}{0.164} \\
\hline Information Quality & \multicolumn{2}{|c|}{$3.500(1.389)$} & $4.358(1.160)$ & \multicolumn{2}{|c|}{0.858} \\
\hline Picture of Product Presentation & \multicolumn{2}{|c|}{$3.700(1.384)$} & $4.158(1.275)$ & \multicolumn{2}{|c|}{0.458} \\
\hline Impulsiveness & \multicolumn{2}{|c|}{$3.574(1.267)$} & $4.614(1.236)$ & \multicolumn{2}{|c|}{1.04} \\
\hline
\end{tabular}

The results showed significant interaction effects of information quality and impulsiveness on the urge to buy impulsively $(\mathrm{F}=5.003, \mathrm{p}=0.026)$. The discrepancy of means indicated that the effect of information quality on the urge to buy impulsively was more evident for low impulsive individuals $(4.125$ - 3.127=1.025) than for the high ones $(4.716-4.434=0.284)$. Hence, though the interaction effect did occur between information quality and impulsiveness, its contrast to our expectation makes hypothesis 6 unsupported. The results also showed that the interaction effects of impulsiveness and number of People's "Like" on the urge to buy impulsively, and the interaction effects of impulsiveness and picture of product presentation on the urge to buy impulsively 
were not significant $(\mathrm{F}=0.357, \mathrm{p}=0.551$, and $\mathrm{F}=0.066, \mathrm{p}=0.797$, respectively). Hence, hypotheses 5 and 7 were not supported.

To gain more understanding, we further tested the possible interaction effects among the independent variables on the urge to buy impulsively. The result demonstrated that there was an interaction effect between information quality and picture of product presentation on the urge to buy impulsively with $F=4.364, p=0.038$, which was significant. Additionally, the discrepancy of means indicated that individuals tend to have more concerns about information quality rather than the picture of product presentation. We described this effect in a plot graph as shown in figure 2 and figure 3.

Table 6 Comparison of Means of Information Quality and Impulsiveness

\begin{tabular}{|c|c|c|c|c|c|}
\hline \multirow[b]{2}{*}{ Dependent Variable } & \multirow{2}{*}{$\begin{array}{c}\text { Information } \\
\text { Quality }\end{array}$} & \multirow[b]{2}{*}{ Impulsiveness } & \multirow[b]{2}{*}{ Mean } & \multicolumn{2}{|c|}{ 95\% Confidence Interval } \\
\hline & & & & $\begin{array}{l}\text { Lower } \\
\text { Bound }\end{array}$ & $\begin{array}{l}\text { Upper } \\
\text { Bound }\end{array}$ \\
\hline \multirow{4}{*}{$\begin{array}{l}\text { Urge to Buy } \\
\text { Impulsively }\end{array}$} & Low & Low & 3.127 & 2.874 & 3.379 \\
\hline & Low & High & 4.432 & 4.022 & 4.841 \\
\hline & High & Low & 4.152 & 3.878 & 4.426 \\
\hline & High & High & 4.716 & 4.371 & 5.062 \\
\hline $\begin{array}{c}\text { Degree of } \\
\text { Impulsiveness }\end{array}$ & \multicolumn{2}{|c|}{$\begin{array}{c}\text { Low Information } \\
\text { Quality }\end{array}$} & \multicolumn{2}{|c|}{$\begin{array}{c}\text { High Information } \\
\text { Quality }\end{array}$} & Difference \\
\hline Low Impulsiveness & \multicolumn{2}{|c|}{3.127} & \multicolumn{2}{|c|}{4.152} & 1.025 \\
\hline High Impulsiveness & \multicolumn{2}{|c|}{4.432} & \multicolumn{2}{|c|}{4.716} & 0.284 \\
\hline
\end{tabular}

Table 7

Comparison of Means of Information Quality And Picture Of Product Presentation

\begin{tabular}{|c|c|c|c|c|c|}
\hline \multirow{2}{*}{$\begin{array}{c}\text { Dependent } \\
\text { Variable }\end{array}$} & $\begin{array}{c}\text { Information } \\
\text { Quality }\end{array}$ & $\begin{array}{c}\text { Picture of Product } \\
\text { Presentation }\end{array}$ & Mean & \multicolumn{2}{|c|}{$\begin{array}{c}\text { 95\% Confidence } \\
\text { Interval }\end{array}$} \\
\cline { 3 - 6 } & Low & Low & 3.433 & 3.068 & 3.798 \\
\hline \multirow{2}{*}{$\begin{array}{c}\text { Urge to Buy } \\
\text { Impulsively }\end{array}$} & Low & High & 4.125 & 3.812 & 4.438 \\
\cline { 2 - 7 } & High & Low & 4.434 & 4.119 & 4.75 \\
\cline { 2 - 6 } & High & High & 4.434 & 4.126 & 4.742 \\
\hline \multirow{2}{*}{$\begin{array}{c}\text { Degree of Picture of Product } \\
\text { Presentation }\end{array}$} & $\begin{array}{c}\text { Low Information } \\
\text { Quality }\end{array}$ & $\begin{array}{r}\text { High Information } \\
\text { Quality }\end{array}$ & Difference \\
\hline Low Picture & 3.433 & \multicolumn{2}{|c|}{4.434} & 1.001 \\
\hline High Picture & 4.125 & \multicolumn{2}{|c|}{4.434} & 0.309 \\
\hline
\end{tabular}




\section{Figure 2}

The Interaction Effects between Information Quality and Impulsiveness on the Urge to Buy Impulsively

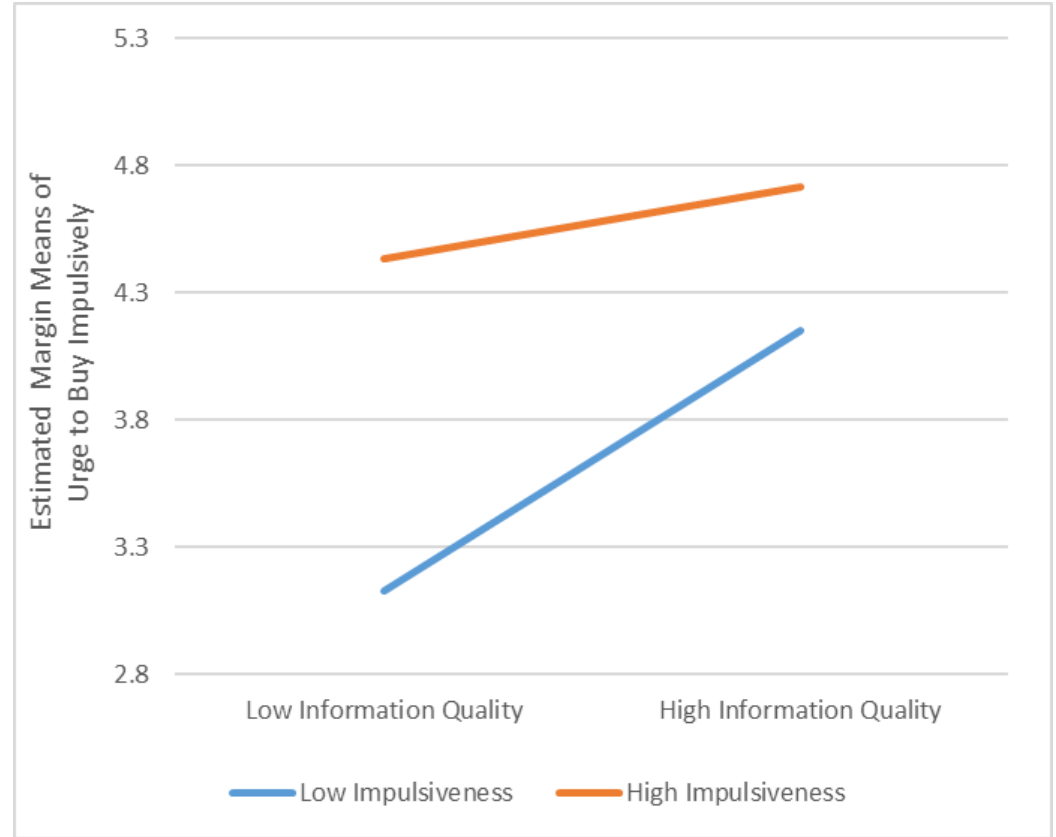

\section{Figure 3}

The Interaction Effects between Information Quality and Picture of Product Presentation on the Urge to Buy Impulsively

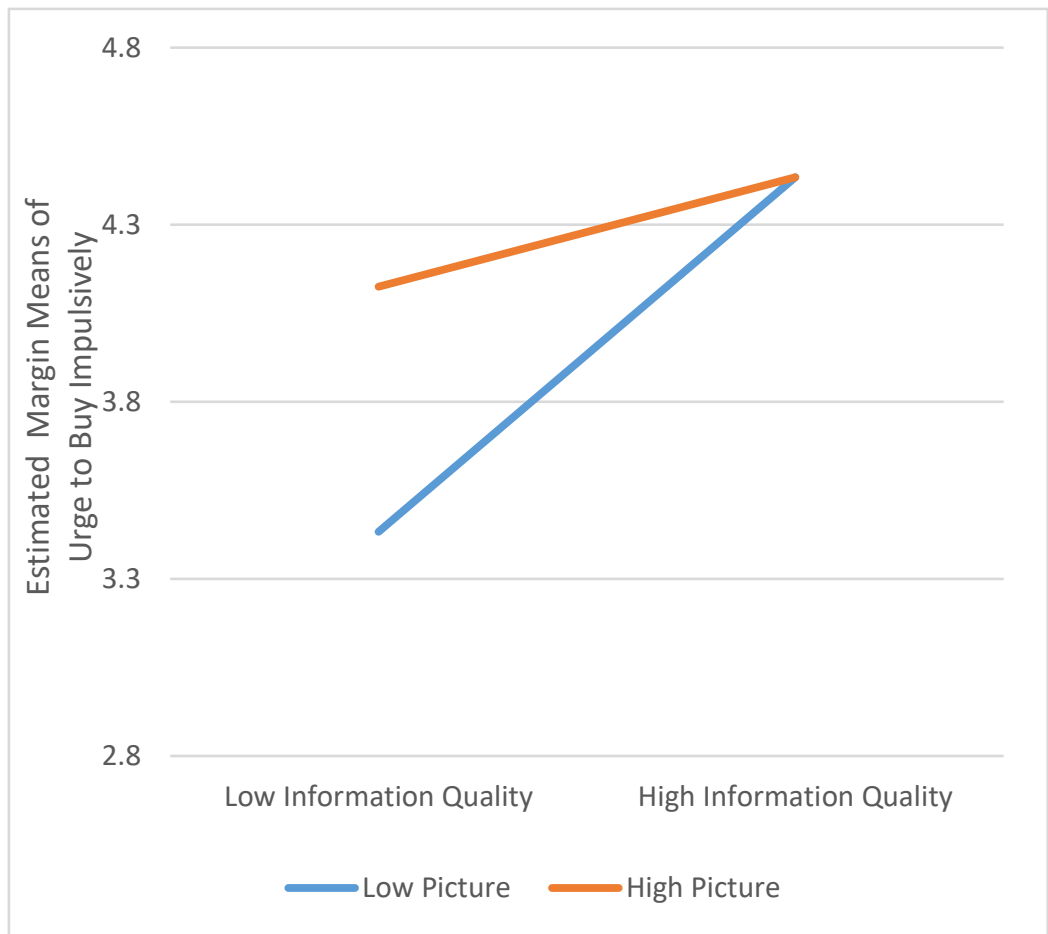




\section{Regression Analysis}

Table 8 shows the regression analysis. The results in model 2 showed that there was a significant positive relationship between information quality and the urge to buy impulsively $(\mathrm{t}$-value $=4.782 ; \mathrm{P}=0.000)$, picture of product presentation and the urge to buy impulsively ( $\mathrm{t}$-value $=2.645 ; \mathrm{P}=0.009$ ), impulsiveness and the urge to buy impulsively ( $\mathrm{t}$-value $=5.260 ; \mathrm{P}=0.000)$. In addition, none of the control variables had a significant effect on the urge to buy impulsively.

Table 8 Regression Analysis

\begin{tabular}{|c|c|c|c|c|c|}
\hline \multirow{2}{*}{\multicolumn{2}{|c|}{ Variables }} & \multicolumn{2}{|c|}{ Model 1} & \multicolumn{2}{|c|}{ Model 2} \\
\hline & & Beta & t-value & Beta & t-value \\
\hline \multirow{10}{*}{ Control } & Age & 0.080 & 1.131 & 0.075 & 1.185 \\
\hline & Education & 0.006 & 0.099 & 0.064 & 1.098 \\
\hline & Employment & 0.083 & 1.248 & 0.050 & 0.859 \\
\hline & Occupation & 0.019 & 0.278 & 0.051 & 0.839 \\
\hline & Income & -0.130 & -1.587 & -0.105 & -1.430 \\
\hline & Spending Budget & 0.055 & 0.698 & -0.013 & -0.177 \\
\hline & Years using on Facebook & -0.111 & -1.585 & -0.101 & -1.614 \\
\hline & Time to play Facebook per day & 0.179 & $2.585 * *$ & 0.106 & 1.701 \\
\hline & Number of friends in Facebook & 0.067 & 0.980 & 0.077 & 1.263 \\
\hline & Change mind & 0.077 & 1.155 & 0.024 & 0.394 \\
\hline \multirow{4}{*}{ Independent } & People's "Like" & & & 0.055 & 0.961 \\
\hline & Information Quality & & & $0.278 * * *$ & 4.782 \\
\hline & Picture of Product Presentation & & & $0.152 * *$ & 2.645 \\
\hline & Impulsiveness & & & $0.309 * * *$ & 5.260 \\
\hline \multicolumn{2}{|l|}{ R Square } & \multicolumn{2}{|c|}{0.082} & \multicolumn{2}{|c|}{0.293} \\
\hline \multicolumn{2}{|c|}{ Adjusted R Square } & \multicolumn{2}{|c|}{0.042} & \multicolumn{2}{|c|}{0.249} \\
\hline \multicolumn{2}{|l|}{ D-W } & \multicolumn{2}{|c|}{2.136} & \multicolumn{2}{|c|}{2.166} \\
\hline \multicolumn{2}{|l|}{ F-value } & \multicolumn{2}{|c|}{2.038} & \multicolumn{2}{|c|}{6.652} \\
\hline \multicolumn{2}{|l|}{ p-value } & \multicolumn{2}{|c|}{0.031} & \multicolumn{2}{|c|}{0.000} \\
\hline
\end{tabular}

\section{DISCUSSION AND IMPLICATIONS}

Table 9 summarized the result of our hypotheses. First, our findings indicated that two elements of environmental cues, information quality and picture of product presentation, play an important role in enhancing the customer's urge to buy impulsively. When an individual is exposed to an advertisement with high information quality, the urge to buy impulsively is more likely to be triggered. Such importance of 
information quality in a consumer's decision-making has been supported by numerous prior studies, such as Chen et al.(2016), Floh and Madlberger (2013), Kim et al.(2008), and Miransa and Saunders (2003). Further study on Facebook B2C social commerce would consider examining specific dimensions of information quality (e.g., relevance, ease of understanding, completeness) to provide a more detailed understanding of the relative importance of each dimension. Moreover, though less impactful than information quality, the attractiveness of the picture shown in the shopping platform also helps to enhance a consumer's subsequent impulsive buying responses considerably.

Contrary to our expectation, the existence of People's "Like" did not exert any significant effect on the consumer's urge to buy impulsively. This finding contradicts Chen et al. (2016)'s previous study on Facebook's C2C social commerce platform, which indicated that the high number of likes would increase individual impulsive buying. Such contradictory results could be explained by several reasons. The first explanation would be attributed to the lack of strictness in the experimental design. To manipulate the People's "Like", we assigned a low level to the post without like and a high level to the post with likes. The number of likes in high condition ranged from 1 to 7 . It is possible that those exposed to 1 or 2 likes would consider it as a low number of likes. Therefore, the result of the manipulation check failed to show that people perceive the difference between low and high conditions. Second, a specific number of likes could play a different role both in C2C (Chen et al., 2016) and B2C social commerce platforms (as demonstrated in our results, supported hypothesis 1). The B2C platform on social network sites often refers to brand pages that have a certain number of followers. The $\mathrm{C} 2 \mathrm{C}$ platform, on the other hand, is a selling/buying group with content generated by ordinary users, who generally have no relationship with other members in the group. Advertisements in the B2C platform are more likely to receive a higher number of likes than those posted in the $\mathrm{C} 2 \mathrm{C}$ group. Consequently, the number of likes to be perceived as high or low would vary depending on each platform. Participants might perceive six likes in a prior study on $\mathrm{C} 2 \mathrm{C}$ social commerce as a high number of likes but as a low level in the B2B platform. Another possible reason suggested by Chen et al. (2016) is that "who" clicked like instead of the number of likes matters more to consumer's behavior. Regardless of the number, if an individual perceives the great social distance with those clicking like in the post, his/her urge to impulsive buying would not significantly be influenced.

Concerning the role of individual traits, it is found that impulsiveness is positively correlated with the consumer's urge to buy impulsively. This finding is consistent with existing evidence in both online and offline contexts, which suggests that those with higher impulsive dispositions tend to experience a greater urge to buy impulsively 
(Beatty \& Ferrell, 1998; Youn \& R. J., 2000). However, different from our expectation, impulsiveness only jointly interacts with information quality to influence the urge to impulsive buying. Accordingly, the impact of information quality on the urge to buy impulsively is more pronounced for low impulsive individuals than those with high impulsive tendencies. This result seems instinctive because, with an increase in the amount of high-quality information, a low impulsive person could have more cues to evaluate, hence, become more open to the urge to buy impulsively. Another reason is that the study's experiment employed a fashion product that is considered greatly attractive to high impulsive individuals. Thus, the level of information quality might not affect them as much as its impact on low impulsive respondents.

Further testing of possible interaction effects demonstrated the significant result of information quality and the picture of product presentation on the urge to buy impulsively. In a low condition of product picture (i.e., the picture is not professional and attractively design), a consumer would experience a greater change in the urge to buy impulsively followed by an increased level of information quality, compared to the high condition of product presentation. This finding sheds light on how to increase impulsive buying behavior when there is a restriction on the display of information or pictures in online product advertisements. Meanwhile, the results of demographic factors and control variables showed that age, education, employment, occupation, income, spending budget, number of years using on Facebook, time to play Facebook per day, number of friends on Facebook are not significantly associated with the urge to buy impulsively. 
Table 9 Hypothesis Summary Results

\begin{tabular}{|c|c|c|}
\hline & Hypothesis & Results \\
\hline $\mathrm{H} 1$ & $\begin{array}{l}\text { Facebook users are likely to have a stronger urge to buy impulsively } \\
\text { under the condition of with People's "Like"rather than without } \\
\text { People's "Like" }\end{array}$ & Not supported \\
\hline $\mathrm{H} 2$ & $\begin{array}{l}\text { Facebook users are likely to have a stronger urge to buy impulsively } \\
\text { under the condition of high information quality rather than low } \\
\text { information quality. }\end{array}$ & Supported \\
\hline $\mathrm{H} 3$ & $\begin{array}{l}\text { Facebook users are likely to have a stronger urge to buy impulsively } \\
\text { under the condition of pictures with professional and attractive } \\
\text { aesthetic design rather than pictures with unprofessional and } \\
\text { unattractive aesthetic design. }\end{array}$ & Supported \\
\hline $\mathrm{H} 4$ & $\begin{array}{l}\text { Facebook users with high impulsiveness will experience a stronger } \\
\text { urge to buy impulsively compared to Facebook users with low } \\
\text { impulsiveness. }\end{array}$ & Supported \\
\hline $\mathrm{H} 5$ & $\begin{array}{l}\text { Impulsiveness Significantly Moderates the Relationship between } \\
\text { People's Like and Urge to Buy Impulsively }\end{array}$ & Not supported \\
\hline H6 & $\begin{array}{l}\text { Impulsiveness Significantly Moderates the Relationship between } \\
\text { Information Quality and Urge to Buy Impulsively }\end{array}$ & Not supported \\
\hline $\mathrm{H} 7$ & $\begin{array}{l}\text { Impulsiveness Significantly Moderates the Relationship between } \\
\text { Picture of Product Presentation and Urge to Buy Impulsively }\end{array}$ & Not supported \\
\hline
\end{tabular}

\section{Theoretical Implications}

This study contributes to the literature on impulsive online buying and social commerce in several ways. First, in light of the latent state-trait theory, we empirically examined the relationship between environmental cues of social commerce platforms and consumers' impulsive buying, as well as its interaction with individual traits. While information quality and picture of product presentation are confirmed to significantly impact subsequent individual response, the number of likes fails to trigger a consumer's response to impulsive buying. Moreover, this research is among few studies that provide salient evidence of the interaction effect of individual characteristics and environmental elements on the urge to buy impulsively. The findings indicated that impulsiveness could only moderate the relationship between information quality and the customer's urge to buy impulsively, while its interaction effect with the number of likes and picture of product presentation quality reported insignificant results. Third, though social commerce has been largely studied, the specific Facebook B2C social platform has not gained sufficient attention in the previous literature. Finally, besides the stimulusresponse-organism framework (S-O-R) - the widely employed theoretical foundation in 
the literature of impulsive buying (Amos et al., 2014), our results strongly indicated that latent state-trait (LST) theory as incorporated in (Chen et al., 2016; Wells et al., 2011) could also be applied to further investigate this online impulse buying phenomenon on social media, thereby extending the applicability of LST in various contexts.

\section{Managerial Implications}

This study provides social commerce practitioners who would like to set up a Facebook store on a Facebook Page with a more insightful understanding of the influence of environmental cues on a customer's buying behavior and its interaction with individual traits. Among three environmental cues examined in this research, information quality has the most significant impact on a customer's urge to buy impulsively. Our results are also in line with a previous study (Chen et al., 2016). The result of the interaction effect also pointed out that for low impulsive individuals, an increased level of information quality would effectively enhance their urge to buy impulsively. These findings would certainly shed light on the critical role of information quality in B2C social commerce platforms. When posting advertisement content on the Facebook page, marketers or online retailers should prioritize information quality over other factors. They should provide sufficient information relevant to products and consider different aspects of information quality, such as ease of understanding, completeness, currency (Chen et al., 2016). Furthermore, the picture of product presentation also significantly affects an individual's urge to buy impulsively. The more professional and aesthetic the picture of the product is, the more likely the customer's urge to buy impulsively is induced. Thus, creating a professional and well-designed product picture should be carefully considered to advertise the products on Facebook.

\section{Limitations and Future Research Directions}

Although this study provides some interesting insights into the social commerce platform, the study is not without limitations. First, we only used fashion products in the experiment, which might affect the dependent variable. Fashion is considered a hedonic product, which is more likely to trigger a consumer's affective response compared to other products (Verhagen \& Van Dolen, 2011). Future studies could employ two products with different natures, such as search and experience products, to gain more comprehensive findings.

Another limitation is that we used wix.com as the main page to ask participants to join the experiment, and from that page, we randomly assigned participants to a different manipulated Facebook page. However, we got some feedback that sometimes they could not access the main link or got stuck at some part of this experiment study when using a smartphone. Next, this study only targeted online female customers in 
Thailand. Further research could look for diverse participants, for example, in terms of gender, nationality, to confirm the important role of environmental cues in a more generalized sample. Moreover, it seems that more environmental cues and individual traits could influence a customer's urge to buy impulsively; hence, it should be considered integrating into the research framework. For example, the act of comments, shares, or those clicking Like might play a part in affecting the urge to buy impulsively. Regarding individual characteristics, product involvement may be a potential variable in the research of impulsive buying. According to Zaichkowsky (1985), product involvement is referred to the perceived relevance of product class, which depends on an individual's inherent interest.

Finally, it could be questioned that there is a possible distinction between a consumer's urge to buy impulsively and actual buying behavior. (Mittal et al., 1999) criticized studies using intention behavior as a proxy measure for actual behavior. Therefore, further research may consider impulse buying behavior as the final dependent variable and investigating the relationship between the urge to buy impulsively and impulse buying behavior in terms of the social network site context.

\section{Conclusion}

In conclusion, drawing from the LST theory, this study has successfully investigated the phenomenon of online impulse buying, in particular for females customers within the context of social commerce (Facebook). Our findings demonstrated that certain factors could influence the female customer's urge to buy impulsively, namely the number of people "Likes", information quality, product presentation, and degree of impulsiveness. By so doing, this study could contribute to the extent of impulse buying literature, as well as provide some valuable insights specifically for the companies who run their businesses on Facebook.

\section{REFERENCES}

Abdelsalam, S., Salim, N., Alias, R. A., \& Husain, O. (2020). Understanding online impulse buying behavior in social commerce: A systematic literature review. IEEE Access, 8. https://doi.org/10.1109/ACCESS.2020.2993671

Amos, C., Holmes, G. R., \& Keneson, W. C. (2014). A meta-analysis of consumer impulse buying. Journal of Retailing and Consumer Services, 21, 86-97. https://doi.org/https://doi.org/10.1016/j.jretconser.2013.11.004

Badgaiyan, A. J., \& Verma, A. (2015). Does urge to buy impulsively differ from impulsive buying behaviour? Assessing the impact of situational factors. Journal of Retailing and Consumer Services, 22, 145-157. https://doi.org/https://doi.org/10.1016/j.jretconser.2014.10.002 
Baggett, P. (1989). Understanding visual and verbal messages. In H. Mandl \& J. R. Levin (Eds.), Advances in psychology: knowledge acquisition from text and pictures (Vol. 58, pp. 101-124). Elsevier Science Publishers. https://doi.org/https://doi.org/10.1016/S0166-4115(08)62150-0

Beatty, S. E., \& Ferrell, M. E. (1998). Impulse buying: Modeling its precursors. Journal of Retailing, 74(2), 169-191. https://doi.org/https://doi.org/10.1016/S0022-4359(99)80092-X

Bharati, P., \& Chaudhury, A. (2006). Product customization on the web: An empirical study of factors impacting choice board user satisfaction. Information Resources Management Journal, 19(2), 69-81. https://doi.org/10.4018/irmj.2006040105

Cao, M., Zhang, Q., \& Seydel, J. (2005). B2C e-commerce web site quality: An empirical examination. Industrual Managment and Data Systems, 105(5), 645661. https://doi.org/https://doi.org/10.1108/02635570510600000

Chan, T. K. H., Cheung, C. M. K., \& Lee, Z. W. Y. (2017). The state of online impulse-buying research: A literature analysis. Information \& Management, 54(2), 204-217. https://doi.org/https://doi.org/10.1016/j.im.2016.06.001

Chen, J. V., Su, B.-c., \& Widjaja, A. E. (2016). Facebook C2C social commerce: A study of online impulse buying. Decision Support Systems, 83, 57-69. https://doi.org/https://doi.org/10.1016/j.dss.2015.12.008

Chen, Q., Clifford, S. J., \& Wells, W. D. (2002). Attitude toward website II: New information. Journal of Advertising Research, 42(2), 33-45. https://doi.org/10.2501/JAR-42-2-33-45

Chen, Y., Lu, Y., Wang, B., \& Pan, Z. (2019). How do product recommendations affect impulse buying? An empirical study on WeChat social commerce. Information \& Management, 56(2), 236-248. https://doi.org/https://doi.org/10.1016/j.im.2018.09.002

Chiang, I.-P., Lin, K.-C., Huang, C.-H., \& Yang, W.-L. (2019). Influence factors of people purchasing on social commerce sites. Contemporary Management Research, 15(2), 69-87. https://doi.org/https://doi.org/10.7903/cmr.18575

ETDA. (2020). Electronic Transactions Development Agency. Retrieved June 12 from https://www.etda.or.th/eng/index.html

Floh, A., \& Madlberger, M. (2013). The role of atmospheric cues in online impulsebuying behavior. Electronic Commerce Research and Applications, 12(6), 425439. https://doi.org/https://doi.org/10.1016/j.elerap.2013.06.001

Hair, J. F., Hult, G. T. M., Ringle, C. M., \& Sarstedt, M. (2014). A primer on partial least squares structural equation modelling (PLS-SEM). Sage Publications, Inc. 
Hair, J., Black, W., Babin, B., \& Anderson, R. (2010). Multivariate data analysis (7th ed.). Prentice-Hall, Inc.

Hajli, M. (2013). A research framework for social commerce adoption. Information Management \& Computer Security, 21(3), 144-154. https://doi.org/https://doi.org/10.1108/IMCS-04-2012-0024

Hajli, N. (2015). Social commerce constructs and consumer's intention to buy. International Journal of Information Management, 35(2), 183-191. https://doi.org/https://doi.org/10.1016/j.ijinfomgt.2014.12.005

Harmancioglu, N., Finney, R. Z., \& Joseph, M. (2009). Impulse purchases of new products: An empirical analysis. Journal of Product and Brand Management, 18(1), 27-37. https://doi.org/https://doi.org/10.1108/10610420910933344

Hennig-Thurau, T., \& Walsh, G. (2003). Electronic word-of-mouth: Motives for and consequences of reading customer articulations on the internet. International Journal of Electronic Commerce, 8(2), 51-74.

https://doi.org/https://doi.org/10.1080/10864415.2003.11044293

Hennig-Thurau, T., Gwinner, K. P., Walsh, G., \& Gremler, D. D. (2004). Electronic word-of-mouth via consumer-opinion platforms: What motivates consumers to articulate themselves on the internet? Journal of Interactive Marketing, 18(1), 38-52. https://doi.org/https://doi.org/10.1002/dir.10073

Hertzog, C., \& Nesselroade, J. R. (1987). Beyond autoregressive models: Some implications of the trait-state distinction for the structural modeling of developmental change. Child Development, 58(1), 93-109. https://doi.org/10.2307/1130294

Jeffrey, S. A., \& Hodge, R. (2007). Factors influencing impulse buying during an online purchase. Electronic Commerce Research, 7(3/4), 367-379. https://doi.org/https://doi.org/10.1007/s10660-007-9011-8

Jiang, Z., \& Benbasat, I. (2007). The effects of presentation formats and task complexity on online consumers' product understanding. MIS Quarterly, 31(3), 475-500. https://doi.org/10.2307/25148804

Kacen, J. J., \& Lee, J. A. (2002). The influence of culture on consumer impulsive buying behavior. Journal of Consumer Psychology, 12(2), 163-176. https://doi.org/https://doi.org/10.1207/S15327663JCP1202_08

Kim, D. J., Ferrin, D. L., \& Rao, H. R. (2008). A trust-based consumer decisionmaking model in electronic commerce: The role of trust, perceived risk, and their antecedents. Decision Support Systems, 44(2), 544-564. https://doi.org/https://doi.org/10.1016/j.dss.2007.07.001

Kim, S., \& Park, H. (2013). Effects of various characteristics of social commerce (scommerce) on consumers' trust and trust performance. International Journal of 
Information Management, 33(2), 318-332.

https://doi.org/https://doi.org/10.1016/j.ijinfomgt.2012.11.006

Kumar, S., \& Mishra, B. (2012). What drives impulse buying? International Journal of Management Sciences, 1(2), 114-123.

Kuo, T., Lu, I. Y., Huang, C. H., \& Wu, C. C. (2005). Measuring users' perceived portal service quality: An empirical study. Total Quality Management and Business Excellence, 16(3), 309-320.

https://doi.org/https://doi.org/10.1080/14783360500053824

Leong, L.-Y., Jaafar, N. I., \& Ainin, S. (2018). The effects of Facebook browsing and usage intensity on impulse purchase in f-commerce. Computers in Human Behavior, 78, 160-173. https://doi.org/https://doi.org/10.1016/j.chb.2017.09.033

Leong, S.M., Ang, S. H., \& Tham, L. L. (1996). Increasing brand name recall in print advertising among Asian customers. Journal of Advertising, 25(2), 65-81. https://doi.org/https://doi.org/10.1080/00913367.1996.10673500

Liang, T.-P., \& Turban, E. (2011). Introduction to the special issue social commerce: a research framework for social commerce. International Journal of Electronic Commerce, 16(2), 5-14.

Liang, T.-P., Ho, Y.-T., Li, Y.-W., \& Turban, E. (2011). What drives social commerce: The role of social support and relationship quality. International Journal of Electronic Commerce, 16(2), 69-90. https://doi.org/https://doi.org/10.2753/JEC1086-4415160204

Liu, P., He, J., \& Li, A. (2019). Upward social comparison on social network sites and impulse buying: A moderated mediation model of negative affect and rumination. Computers in Human Behavior, 96, 133-140. https://doi.org/https://doi.org/10.1016/j.chb.2019.02.003

Liu, Y., Li, H., \& Hu, F. (2013). Website attributes in urging online impulse purchase: An empirical Investigation on consumer perceptions. Decision Support Systems, 55(3), 829-837. https://doi.org/https://doi.org/10.1016/j.dss.2013.04.001

Lo, L. Y.-S., Lin, S.-W., \& Hsu, L.-Y. (2016). Motivation for online impulse buying: A two-factor theory perspective. International Journal of Information Management, 36(5), 759-772. https://doi.org/https://doi.org/10.1016/j.ijinfomgt.2016.04.012

Lu, K.-H., \& Wu, C.-M. (2019). Moderating effects of shopping values on antecedents of unplanned purchase behavior: An empirical study of an international travel fair. Contemporary Management Research, 15(2), 123-145. https://doi.org/https://doi.org/10.7903/cmr.19136 
Lyer, G. R., Blut, M., Xiao, S. H., \& Grewal, D. (2020). Impulse buying: a metaanalytic review. Journal of the Academy of Marketing Science volume 48, 384404. https://doi.org/https://doi.org/10.1007/s11747-019-00670-w

March, R., \& Woodside, A. G. (2005). Tourism behaviour: Travellers' decisions and actions. CABI Publishing.

Miransa, S. M., \& Saunders, C. S. (2003). The social construction of meaning: An alternative perspective on information sharing. Information Systems Research, 14(1), 87-107. https://doi.org/https://doi.org/10.1287/isre.14.1.87.14765

Mithas, S., Ramasubbu, N., Krishnan, M. S., \& Fornell, C. (2007). Designing web sites for customer loyalty across business domains: A multilevel analysis. Journal of Management Information Systems, 23(3), 97-127. https://doi.org/https://doi.org/10.2753/MIS0742-1222230305

Mittal, V., Kumar, P., \& Tsiros, M. (1999). Attribute-level performance satisfaction, and behavioral intentions over time: A consumption-system approach. Journal of Marketing, 63(2), 88-101. https://doi.org/10.2307/1251947

Miyoung, J., \& Jiyoung, C. (2008). Effects of picture presentations on costomers' behavioral intention on the web. Journal of Travel \& Tourism Marketing, 17(23), 193-204. https://doi.org/https://doi.org/10.1300/J073v17n02_15

Montoya-Weiss, M. M., Voss, G. B., \& Grewal, D. (2003). Determinants of online channel use and overall satisfaction with a relational, multichannel service provider. Journal of the Academy of Marketing Science, 31(4), 448-458. https://doi.org/https://doi.org/10.1177/0092070303254408

Nunnally, J. C., \& Bernstein, I. H. (1994). Psychometric theory (3rd ed.). McGrawHill,Inc.

Parboteeah, D. V., Valacich, J. S., \& Wells, J. D. (2009). The influence of website characteristics on a consumer's urge to buy impulsively. Information Systems Research, 20(1), 60-78. https://doi.org/https://doi.org/10.1287/isre.1070.0157

Pual, D., \& Richard, K. (2010). Facebook marketing for dummies. Wiley Publishing, Inc.

Ramsaran-Fowdar, R. R., \& Fowdar, S. (2013). The Implications of Facebook marketing for organization. Contemporary Management Research, 9(1), 73-84. https://doi.org/doi:10.7903/cmr.9710

Rook, D. W., \& Fisher, R. J. (1995). Normative influences on impulsive buying behavior. Journal of Consumer Research, 22(3), 305-313. https://doi.org/https://doi.org/10.1086/209452

Setyani, V., Zhu, Y.-Q., Hidayanto, A. N., Sandhyaduhita, P. I., \& Hsiao, B. (2019). Exploring the psychological mechanisms from personalized advertisements to urge to buy impulsively on social media. International Journal of Information 
Management, 48, 96-107.

https://doi.org/https://doi.org/10.1016/j.ijinfomgt.2019.01.007

Steyer, R., Schmitt, M., \& Eid, M. (1999). Latent state-trait theory and research in personality and individual differences. European Journal of Personality, 13(5), 389-408. https://doi.org/https://doi.org/10.1002/(SICI)10990984(199909/10)13:5<389::AID-PER361>3.0.CO;2-A

Sundström, M., Hjelm-Lidholm, S., \& Radon, A. (2019). Clicking the boredom away - Exploring impulse fashion buying behavior online. Journal of Retailing and Consumer Services, 47, 150-156.

https://doi.org/https://doi.org/10.1016/j.jretconser.2018.11.006

Teh, P.-L., \& Ahmed, P. K. (2012). Understanding social commerce adoption: An extension of the Technology Acceptance Model. 2012 IEEE International Conference on Management of Innovation \& Technology (ICMIT), Bali.

Unnava, H. R., \& Burnkrant, R. E. (1991). An imagery-processing view of the role of pictures in print advertisment. Journal of Marketing Research, 28(2), 226-231. https://doi.org/10.2307/3172811

Vance, A., Elie-Dit-Cosaque, C., \& Straub, D. W. (2008). Examining trust in information technology artifacts: The effects of system quality and culture. Journal of Management Information Systems, 24(4), 73-100. https://doi.org/https://doi.org/10.2753/MIS0742-1222240403

Vazquez, D., Wu, X., Nguyen, B., Kent, A., Gutierrez, A., \& Chen, T. (2020). Investigating narrative involvement, parasocial interactions, and impulse buying behaviours within a second screen social commerce context. International Journal of Information Management, 53. https://doi.org/https://doi.org/10.1016/j.ijinfomgt.2020.102135

Verhagen, T., \& Van Dolen, W. (2011). The influence of online store beliefs on consumer online impulse buying: A model and empirical application. Information \& Management, 48(8), 320-327. https://doi.org/https://doi.org/10.1016/j.im.2011.08.001

Vonkeman, C., Verhagen, T., \& Dolen, W. v. (2017). Role of local presence in online impulse buying. Information \& Management, 54(8), 1038-1048. https://doi.org/http://dx.doi.org/10.1016/j.im.2017.02.008

Wang, C., \& Zhang, P. (2012). The evolution of social commerce: The people, management, technology, and information dimensions. CAIS, 31(5). https://doi.org/0.17705/1CAIS.03105

Well, J. D., Valacich, J. S., \& Hess, T. J. (2011). What signal are you sending? How website quality influences perceptions of product quality and purchase intention. MIS Quarterly, 35(2), 373-396. https://doi.org/10.2307/23044048 
Wells, J. D., Parboteeah, V., \& Valacich, J. S. (2011). Online impulse buying: Understanding the interplay between consumer impulsiveness and website quality. Journal of the Association for Information Systems, 12(1), 226-254. https://doi.org/10.17705/1jais.00254

Wixom, B. H., \& Todd, P. A. (2005). A theoretical integration of user satisfaction and technology acceptance. Information Systems Research, 16(1), 85-102. https://doi.org/https://www.jstor.org/stable/23015766

Wu, I.-L., Chiu, M.-L., \& Chen, K.-W. (2020). Defining the determinants of online impulse buying through a shopping process of integrating perceived risk, expectation-confirmation model, and flow theory issues. International Journal of Information Management, 52. https://doi.org/https://doi.org/10.1016/j.ijinfomgt.2020.102099

Wu, Y., Xin, L., \& Li, D. (2020). How does scarcity promotion lead to impulse purchase in the online market? A field experiment. Information \& Management. https://doi.org/https://doi.org/10.1016/j.im.2020.103283

Xiang, L., Zheng, X., Lee, M. K. O., \& Zhao, D. (2016). Exploring consumers' impulse buying behavior on social commerce platform: The role of parasocial interaction. International Journal of Information Management, 36, 333-347. https://doi.org/https://doi.org/10.1016/j.ijinfomgt.2015.11.002

Xu, H., Zhang, K. Z. K., \& Zhao, S. J. (2020). A dual systems model of online impulse buying. Industrial Management \& Data Systems, 120(5), 845-861. https://doi.org/https://doi.org/10.1108/IMDS-04-2019-0214

Yadav, M. S., Valck, K. D., Hennig-Thurau, T., Hoffman, D. L., \& Spann, M. (2013). Social commerce: A contingency framework for assessing marketing potential. Journal of Interactive Marketing, 27(4), 311-323. https://doi.org/https://doi.org/10.1016/j.intmar.2013.09.001

Youn, S., \& Faber, R. J. (2000). Impulse buying: Its relation to personality traits and cues. Advances in Consumer Research, 27(1), 179-185. https://doi.org/https://www.acrwebsite.org/volumes/8383/volumes/v27/NA-27

Zaichkowsky, J. L. (1985). Measuring the involvement construct. Journal of Consumer Research, 12(3), 341-352. https://doi.org/https://doi.org/10.1086/208520

Zhang, K. Z., \& Benyoucef, M. (2016). Consumer behavior in social commerce: A literature review. Decision Support Systems, 86, 95-108. https://doi.org/https://doi.org/10.1016/j.dss.2016.04.001

Zhang, X., Prybutok, V. R., \& Koh, C. E. (2006). The role of impulsiveness in a TAM-based online purchasing behavior model. Information Resources 
Management Journal, 19(2), 54-68. https://doi.org/10.4018/978-1-59904-5702.ch019

Zheng, X., Men, J., Yang, F., \& Gong, X. (2019). Understanding impulse buying in mobile commerce: An investigation into hedonic and utilitarian browsing. International Journal of Information Management, 48, 151-160. https://doi.org/https://doi.org/10.1016/j.ijinfomgt.2019.02.010

Dr. Jengchung Victor Chen is a distinguished professor of the Institute of International Management, National Cheng Kung University, Taiwan. He has a Ph.D. in CIS from the University of Hawaii, U.S.A. He has published more than 80 papers in international authoritative journals, including Computers in Human Behavior, Information \& Management, Decision Support Systems, Journal of the Association for Information Systems, International Journal of Electronic Commerce, European Journal of Information Systems, Internet Research, Journal of Computer Information Systems, International Journal of Mobile Communications, Journal of Systems and Software, Industrial Management and Data Systems, International Journal of Energy Research, Computer Standards \& Interfaces, and many others.

Ms. Waranuch Chotimapruek earned her M.B.A. from the Institute of International Management, National Cheng Kung University, Taiwan. Her research interests are social commerce and consumer behaviors.

Dr. Quang-An Ha is currently teaching at the University of Economics in Ho Chi Minh City, Vietnam. He earned his Ph.D. from Institute of International Management, National Cheng Kung University, Taiwan. His research has been published in Computers in Human Behavior, Journal of Global Information Technology Management, International Journal of Mobile Communications, International Journal of Energy Economics, Contemporary Management Research, and several international conference proceedings. His research interests include social business, network psychology, and human-computer interaction.

Dr. Andree E. Widjaja (Corresponding author) is an Assistant Professor in Department of Information System, Pelita Harapan University, Indonesia. He received his Ph.D. from the Institute of International Management, National Cheng Kung University, Taiwan. His research has been published in several international authoritative journals: Computer in Human Behavior, Decision Support Systems, International Journal of Human-Computer Interaction, Enterprise Information Systems, Information Systems Frontiers, International Journal of Mobile Communications, International Journal of Cyber Behavior, Psychology, and Learning, and several others. 